\title{
FLEXURAL BEHAVIOR OF THE STRUCTURAL CONCRETE REINFORCED WITH STEEL AND POLYPROPYLENE FIBERS
}

\author{
Elmer Luis Cuenca Briceño, Cristhy Stephany Solórzano Rodríguez \\ and Marlon Farfán Córdova \\ Universidad César Vallejo, Trujillo, Perú
}

\begin{abstract}
In this investigation, the effect of steel and polypropylene fibers on the flexural strength of structural concrete was evaluated. The granulometric properties of the aggregates were analyzed under the norms ASTM C136 and NTP 400.012, with the results obtained, the mixture design was made with a characteristic resistance to the compression of $210 \mathrm{Kg} / \mathrm{cm}^{2}$, to which proportions of $10 \%, 15 \%$ and $20 \%$ of steel and polypropylene fibers were added. Fine and coarse aggregate (1/2" stone), Portland cement Type ICo, steel fibers (Sika Fiber CHO 65/35 NB) and polypropylene fibers (Sika Fiber PE) were used. Forty-eight 150x150x600 mm concrete beams were produced in three experimental groups and a control group, which were tested for flexural strength according to ASTM C78 and NTP 339.078, after 14 and 28 days of curing. Maximum values were achieved after 28 days with $30.1 \mathrm{~kg} / \mathrm{cm} 2$ for standard concrete and $32.5 \mathrm{~kg} / \mathrm{cm}^{2}$ for concrete with $20 \%$ steel fiber and polypropylene. The fibers proved to be an excellent aggregate to be used in concrete mixtures because they significantly improve its physical and mechanical characteristics. Fiberreinforced concrete with a $20 \%$ proportion achieved a $7.7 \%$ increase in strength over standard concrete, concluding that a concrete with added steel fibers and polypropylene has a better performance compared to conventional concrete.
\end{abstract}

Keywords: Steel fibers, polypropylene fibers, flexural strength, structural concrete.

Cite this Article: Elmer Luis Cuenca Briceño, Cristhy Stephany Solórzano Rodríguez and Marlon Farfán Córdova, Flexural Behavior of the Structural Concrete Reinforced with Steel and Polypropylene Fibers. International Journal of Civil Engineering and Technology, 11(5), 2020, pp. 137-145.

https://iaeme.com/Home/issue/IJCIET?Volume=11\&Issue=5

\section{INTRODUCTION}

Concrete is one of the most used elements in the construction industry, due to the contributions of its physical and mechanical properties such as its versatility, workability, durability and resistance [1] [2].

Adding fibers to concrete to decrease the expansion of failures, due to weakness in tension and drying contraction [3], not only develops compressive, tensile and flexural strength, but 
also provides adequate response before and after cracking. Since 1967, various types of filaments have been successfully used in concrete to limit crack propagation and improve ductility and strength [4]. Experimental studies have shown the ability of the fibers to provide better response to seismic stresses.

\section{METHODS AND MATERIALS}

An experimental research design with post-test only and control group was used [5]. Initially, the granulometric analysis of the materials was performed following the procedures described in ASTM C136 [6] and NTP 400.012 [7]. A sample of 48 prismatic rectangular specimens of 150x150x600 mm was worked with according to the ASTM C192 standard [8], distributed evenly for the experimental and control groups, according to 14 and 28 days of curing.

The experimental samples were increased $10 \%, 15 \%$ and $20 \%$ of steel and polypropylene fibers. High-quality drawn steel fibers of Sika Fiber CHO 65/35 NB [9] were used to facilitate the homogenization of the concrete by preventing the agglomeration of the individual fibers Sika Fiber PE polypropylene fibers were also used. This is a high-tenacity synthetic reinforcement that prevents cracking in concrete and mortar, and is composed of a mixture of crosslinked and rolled monofilaments.

During mixing, Sika Fiber PE is randomly distributed within the concrete or mortar mass, forming a very uniform three-dimensional network. A mix design was developed for a compressive strength of $f^{\prime} \mathrm{c}=210 \mathrm{Kg} / \mathrm{cm}^{2}$ in which both fine and coarse aggregate $(1 / 2$ " stone), Portland cement Type ICo and subsequently steel fibers (Sika Fiber CHO 65/35 NB) and polypropylene fibers (Sika Fiber PE) were used for the experimental samples.

The technical standards NTP 339.035 [10], NTP 339.078 [11] and ASTM C78 [12] were used to perform the corresponding tests. The 150x150x600 mm test beam was symmetrically supported by two parallel steel rollers with a separation distance of $45 \mathrm{~cm}$.

The load was applied through two rollers mounted on a metal plate which in turn was loaded at the central point (Method of testing on beams simply supported with loads to the third of the section). The flexural strength was measured through the modulus of rupture $R=$ $p l / b d^{2}$, where p: maximum applied load, l: free length between supports (mm), b: average width of the sample $(\mathrm{mm})$, d: average height of the sample $(\mathrm{mm})$. See figure 1.

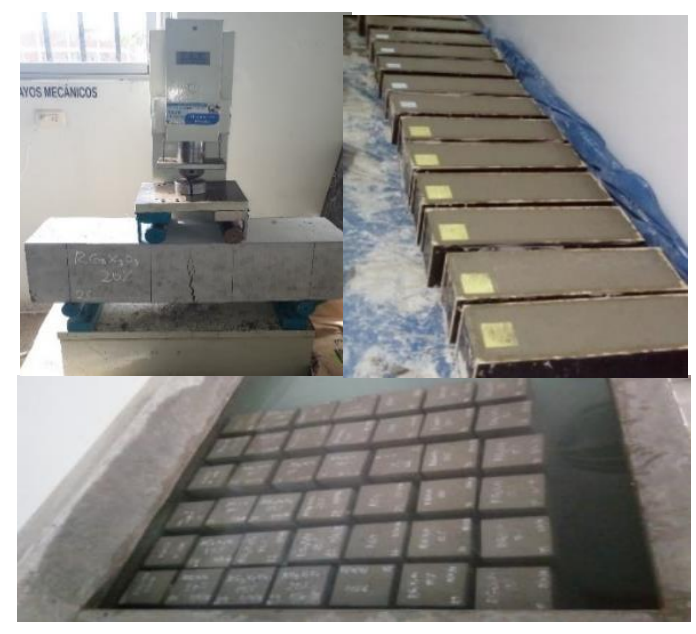

Figure 1 Curing and testing of concrete samples 


\section{RESULTS}

\subsection{Characterization of Materials and Design of Mixtures}

Figures 2 and 3 show the granulometry of the fine and coarse aggregates obtained from the tests carried out, according to ASTM C136 [6] and NTP 400.012 [7].

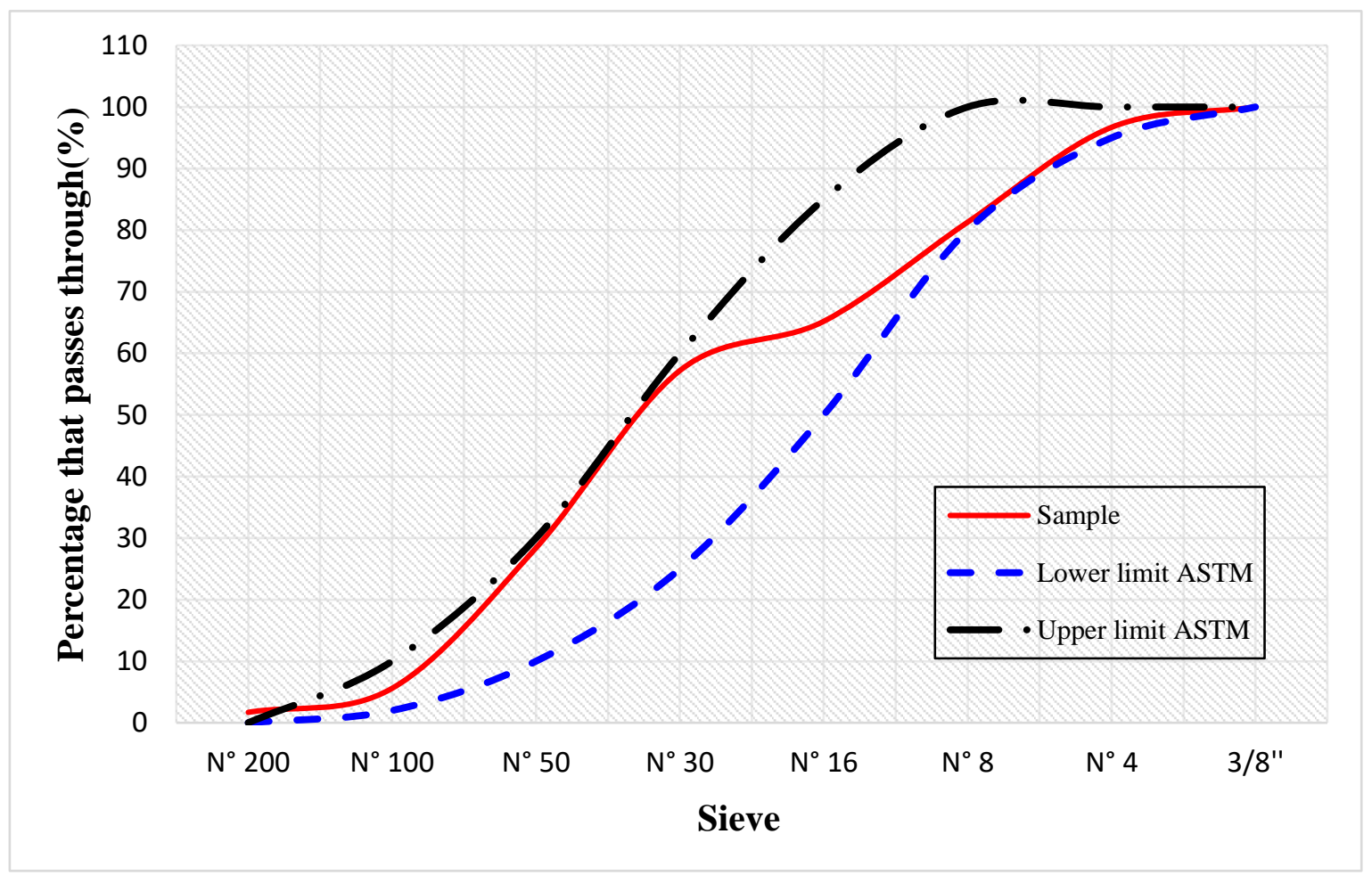

Figure 2 Granulometric curve of fine aggregate - specification limits ASTM C33 [13].

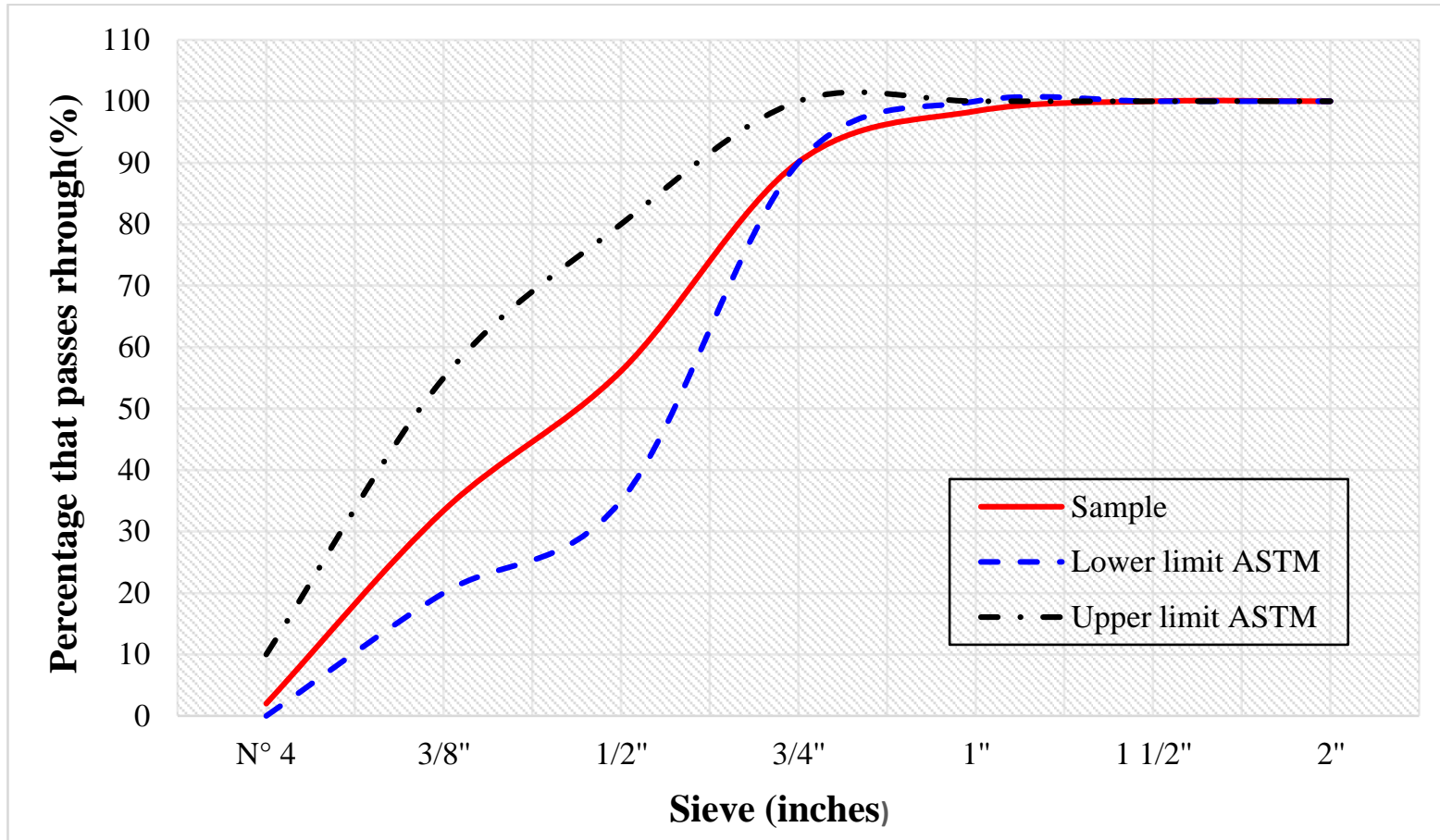

Figure 3 Granulometric curve of coarse aggregate - specification limits ASTM C33 [13]. 
Flexural Behavior of the Structural Concrete Reinforced with Steel and Polypropylene Fibers

Table 1 shows the physical-chemical characteristics of Pacasmayo Extraforte Cement (Type ICo), provided by the manufacturer [14]. The mixture design was made using the 211 ACI Committee Method [15], being the proportions used as indicated in table 2.

Table 1 Physical-chemical and mechanical characteristics of cement.

\begin{tabular}{llc}
\hline \multicolumn{1}{c}{ Chemical Properties } & \multicolumn{1}{c}{ Requirement NTP 334.090 [16] } & Result \\
\hline $\mathrm{MgO}$ & Maximum 6\% & $2.3 \%$ \\
$\mathrm{SO} 3$ & Maximum $4 \%$ & $2.4 \%$ \\
\hline \multicolumn{2}{c}{ Physical and mechanical properties } \\
\hline Air content & Maximum $12 \%$ & $5 \%$ \\
Specific surface & It does not specify & $5440 \mathrm{~cm}^{2} / \mathrm{gr}$ \\
Density & It does not specify & $2.96 \mathrm{gr} / \mathrm{ml}^{2}$ \\
Compression resistance at 3 days & Mínimum $133 \mathrm{~kg} / \mathrm{cm}^{2}$ & $206 \mathrm{~kg} / \mathrm{cm}^{2}$ \\
Compression resistance at 7 days & Mínimum $204 \mathrm{~kg} / \mathrm{cm}^{2}$ & $264 \mathrm{~kg} / \mathrm{cm}^{2}$ \\
Compression resistance at 28 days & Mínimum $255 \mathrm{~kg} / \mathrm{cm}^{2}$ & $335 \mathrm{~kg} / \mathrm{cm}^{2}$ \\
Initial curing & Mínimum $45(\mathrm{~min})$ & $124 \mathrm{~min}$ \\
Final curing & Maximum $420(\mathrm{~min})$ & $254 \mathrm{~min}$ \\
\hline
\end{tabular}

Table 2 Design of concrete mixtures for $f^{\prime} \mathrm{c}=210 \mathrm{~kg} / \mathrm{cm}^{2}$ with a/c ratio of 0.60

\begin{tabular}{cccc}
\hline Material & Weight Ratio & Weight in Kg & \% of mixture \\
\hline Cement & 1,00 & 345,6 & 14,9 \\
Sand & 1,96 & 678,2 & 29,3 \\
Gravel & 3,14 & 1086,6 & 46,9 \\
Water & 0,60 & 208,1 & 9,0 \\
\hline \multicolumn{2}{r}{ Total for $1 \mathrm{~m}^{3}$} & 2318,5 & 100,0 \\
\hline
\end{tabular}

\subsection{Testing of Concrete in a Fresh and Hardened State}

The slump test was conducted in accordance with NTP 339.035 [10] and ASTM C143 [17], which serves to determine the consistency or fluidity of the mixture. The results of this test are shown in Table 3.

Table 3 Maximum fresh concrete slump

\begin{tabular}{lcc}
\hline \multicolumn{1}{c}{ Group } & SLUMP (inches) & \% Variation \\
\hline SC & 3.75 & $0 \%$ \\
SC10SPF & 3.60 & $-4.0 \%$ \\
SC15SPF & 3.55 & $-5.3 \%$ \\
SC20SPF & 3.50 & $-6.7 \%$ \\
\hline
\end{tabular}

Flexural strength tests, on samples of hardened concrete, were performed according to ASTM C78 [12] and NTP 339.078 [11], whose results are shown in Table 5 and Figures 4 and 5 .

Table 4 Flexural strength in concrete beams in a hardened state at different curing ages.

\begin{tabular}{lllllll}
\hline Mixture & \multicolumn{7}{l}{ Resistance to flexion $(\mathrm{Kg} / \mathrm{cm} 2)$} \\
\cline { 2 - 7 } & 14 days & \% scope & $\begin{array}{l}\text { Maximum } \\
\text { deformation } \\
(\mathrm{mm})\end{array}$ & 28 days & $\begin{array}{l}\% \\
\text { scope }\end{array}$ & $\begin{array}{l}\text { Maximum } \\
\text { deformation } \\
(\mathrm{mm})\end{array}$ \\
\hline SC & $29.8^{*}$ & 80.0 & 1.7 & 30.1 & $100.0^{*}$ & 1.8 \\
SC10SPF & 28.6 & 76.9 & 1.7 & 30.9 & 102.4 & 1.8 \\
SC15SPF & 25.9 & 69.8 & 1.5 & 30.1 & 99.9 & 1.8 \\
SC20SPF & 27.8 & 74.7 & 1.6 & 32.5 & 107.7 & 1.9 \\
\hline
\end{tabular}

Note: *Strength tolerance according to the age of curing of the concrete. NTP 339,034 [18] 
Elmer Luis Cuenca Briceño, Cristhy Stephany Solórzano Rodríguez and Marlon Farfán Córdova

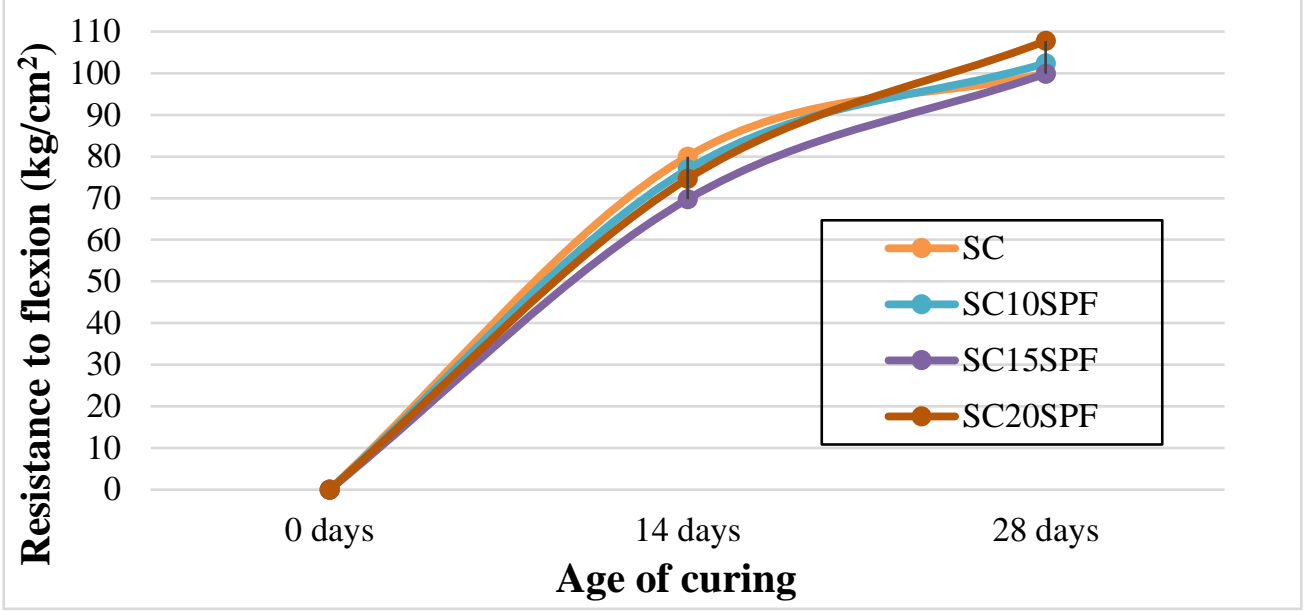

Figure 4 Flexural strength of concrete according to curing age.

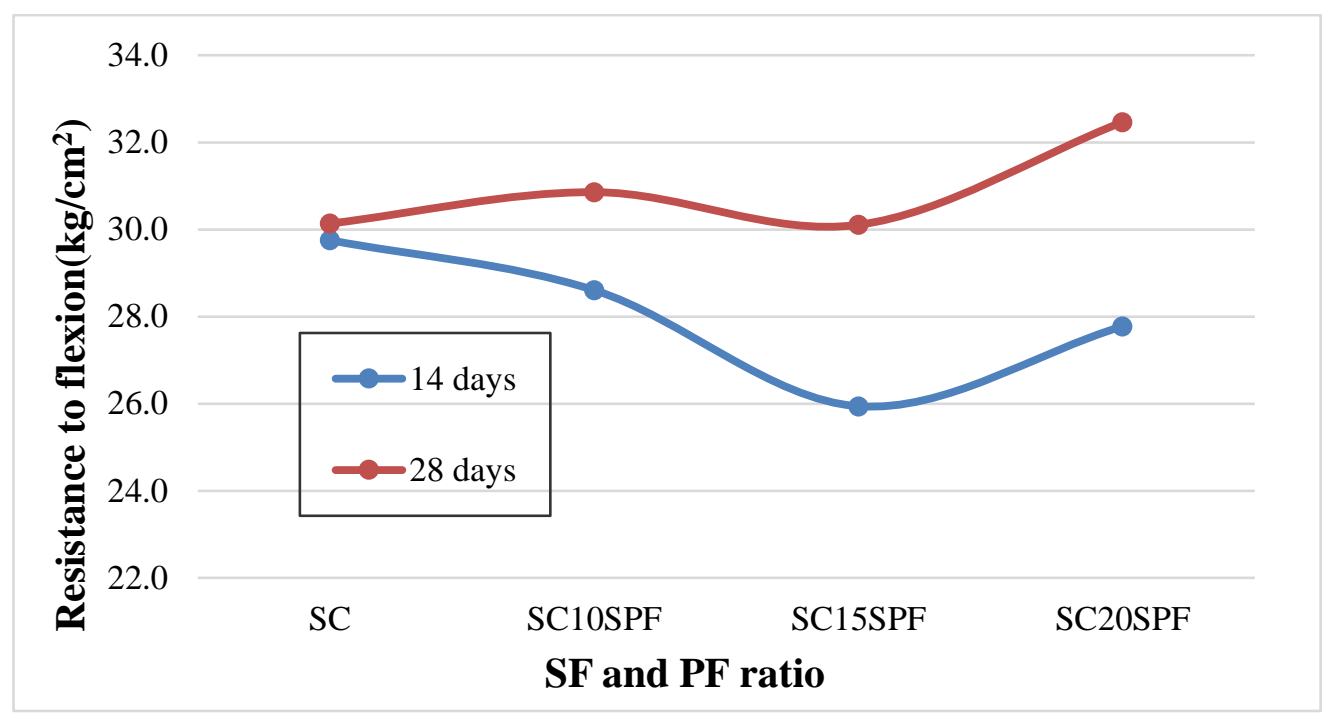

Figure 5 Flexural strength of concrete according to different proportions of SF and PF fibers.

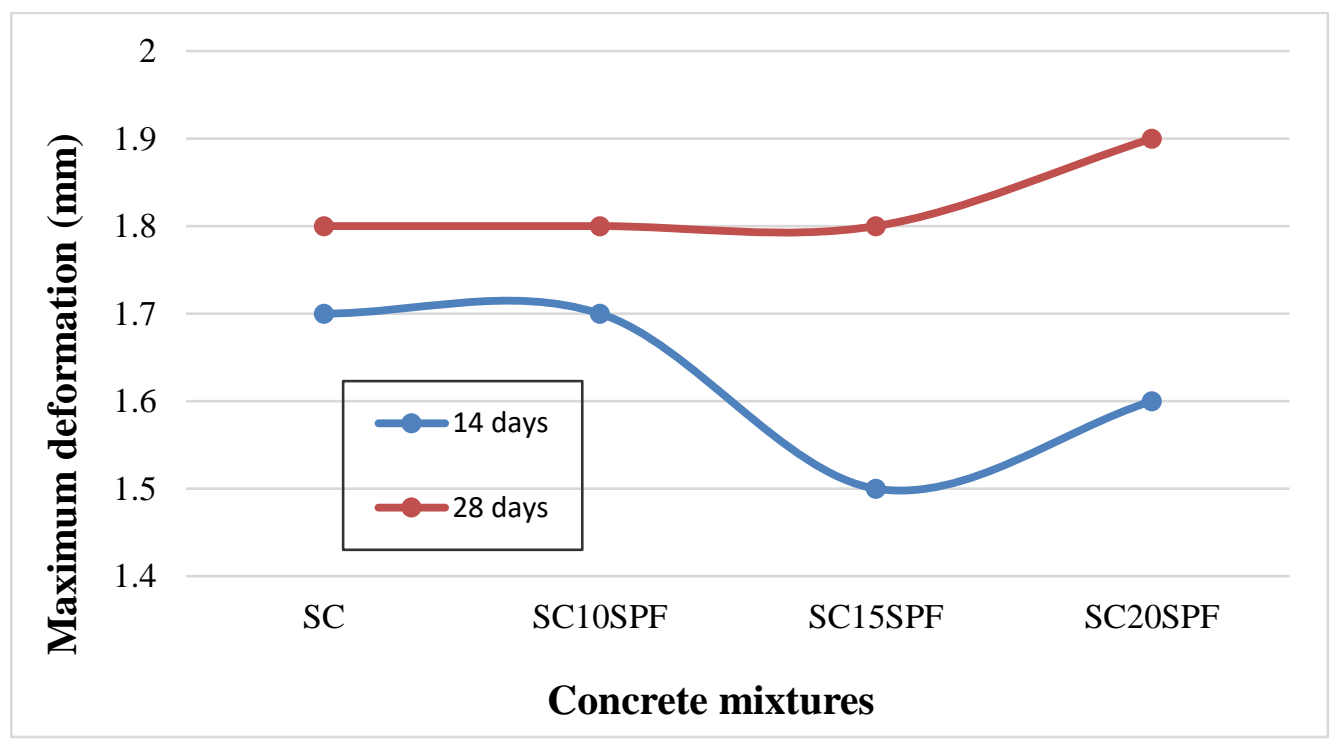

Figure 6 Maximum deformation according to proportion of SF and PF fibers. 


\subsection{Statistical Analysis of Results}

The samples tested at 28 days of age met the normality test ( $>>0.05)$ with the exception of the CS mixture $(\mathrm{p}<0.05)$, and therefore the Kruskal-Wallis statistical test was used as detailed in Table 5.

Table 5 Kruskal - Wallis for flexural strength values of concrete specimens tested at 28 days of age

\begin{tabular}{cc}
\hline Test statistic & Values \\
\hline H of Kruskal-Wallis & 4.451 \\
gl. & 3 \\
Asymptotic significance & 0.217 \\
\hline
\end{tabular}

The non-parametric Kruskal Wallis test determined that $\mathrm{p}=0.217>0.05$, therefore, the averages of the modified mixtures (SC10SPF, SC15SPF and SC20SPF) do not show a significant difference from the SC mixture (Table 5 and Figure 4).

\section{DISCUSSION OF RESULTS}

\subsection{Slump}

It was observed that slump decreases as the proportion of steel and polypropylene fibers in the concrete mix increases (decrease up to $6.7 \%$, table 3); this situation is due to the need for mortar due to the formation of a very uniform three-dimensional network with both fibers. The differences can be seen in table 3. These variations in slump are also found by [19], [20], [21], [22], [23], in some cases they came to use and/or recommend the use of plasticizing additives to improve the workability of the concrete. Patil and Shinde (2016) [24] also determined that increasing the steel fiber in the concrete decreases its workability.

\subsection{Flexural Strength}

Table 4 details the average values of the flexural strength of the specimens in the studied proportions. It is observed that the resistance has a maximum decrease of 10.2\% (SC15SPF) in the fiber-reinforced specimens at 14 days of cure, considering that the SC reaches $80 \%$ of its resistance. Unlike the previous specimens, at 28 days all the fibre-reinforced mixtures were equal to or higher than SC, with the SC20SPF obtaining an increase of $7.7 \%$ in the modulus of rupture having a control function against the propagation of micro-flaws. Badogiannis, Christidis and Tzanetatos (2019) [25] report that the combination of SF and PF increases the flexural strength from $47 \%$ to $110 \%$, referring that this is due to the type and shape of the steel fiber [26] that allowed to control the development of cracks increasing its strength and toughness even after cracking had started. This control of structural cracks is also confirmed by [19], [27] and [28].

On the other hand, Mastali, Dalvand, Sattarifard, Abdollahnejad and IIIikainen (2018) [29] detail that the type of fiber (SF and PF), the combination or the proportion can improve the ability of the mixtures to stop the propagation of cracks, mainly fibers of industrial origin. The incorporation of FP alone into concrete also helps to improve strength, as confirmed by Mashrei, Sultan and Mahdi (2018) [30] who found an increase of up to 104\% over standard concrete, when used up to a certain ratio, helping to reduce the width of cracks. For their part, Al-Katib, Alkhudery and Al-Tameemi (2018) [31] found that flexural strength increases considerably when the PF ratio is increased, with increases ranging from $72 \%$ to $277 \%$ when PF ranged from 0.5 to $3.5 \%$, which is favorable for counteracting additional load cycles; they also claim that flexural strength can be further increased when combined with improved cement. 
Chapoñan and Quispe (2017) [32], Sarta and Silva (2017) [20], Armas (2016) [21], Condori (2015) [33] and Ortiz (2015) [22], also found that the addition of fibers generates an increase in the flexural strength of the concrete, and when using plasticizing additive in the mix, a higher value is achieved in the modulus of rupture, since it has the property of increasing the mechanical strength and improving the workability of the mix. It should be highlighted that the increases in flexural strength can be attributed to the action of the fibers in their purpose of preventing the propagation of micro-cracks in the concrete when it is subjected to solicitations, restricting their extension or elongation.

On the other hand, during the tests in both ages of curing, it was observed that the SC specimens presented fragile faults reaching total collapse, unlike the specimens with added fibers in proportions of $10 \%, 15 \%$ and $20 \%$ that presented ductile faults, that is to say that when applying the loads in the element, cracking was present in its central third, but the beam remained firm due to the presence of fibers. Sarta and Silva (2017) [20], Condori (2015) [33], Ortiz (2015) [22] and Millán (2013) [34] state that the presence of fibers changes the behavior from a fragile break to a ductile one.

With regard to the maximum deformation reached after 28 days of curing, Figure 5 shows that the highest value reached in the SC20SPF sample was $1.9 \mathrm{~mm}$, which is $5.6 \%$ higher than the simple concrete (SC) design without fibers.

\subsection{Statistical Analysis}

With regard to the effect of the dosage of SF and PF on the flexural strength of the concrete, table 5 shows that there is no differentiated behavior, but the sample that reached a better development at 28 days of curing, above SC, was SC20SPF (Figure 5). Although these values are not statistically significant, it was evident that the addition of steel and polypropylene fibers generate an increase in the flexural strength of the concrete.

\section{CONCLUSIONS}

- $\quad \mathrm{SF}$ and PF fibers proved to be an excellent aggregate to be used in concrete mixtures because they significantly improve its physical and mechanical characteristics.

- Fiber-reinforced concrete with a proportion of $20 \%$ of SF and PF achieved an increase of the modulus of rupture of $7.7 \%$ with respect to the simple concrete, letting us affirm that this concrete has a better behavior compared to a conventional concrete.

- The maximum deformation reached was $1.9 \mathrm{~mm}$ in the SC20SPF sample at 28 days of cure, representing 5.6\% higher than simple concrete (SC) without fibers.

- Fiber-reinforced mixtures do not present a significant statistical difference despite having exceeded the bending performance of conventional concrete (SC) by up to $7.7 \%$ at 28 days of cure.

- Concrete specimens that included the combination of SF and PF reduce the presence of cracks and can withstand additional load cycles after failure loading is released.

\section{REFERENCES}

[1] Nagaraja, K.Y Sudarshan, H. An Experimental Investigation of Ternary Blended Hybrid Fiber Reinforced Concrete (MK: FA: GGBS): Steel \& Polypropylene Fibers. International Journal of Advanced Research in Engineering and Technology (IJARET), 10(6), 2019, 202-216.

[2] Srinivasan, K. Durability studies on the slag based geopolymer concrete strengthened with steel fibres. International Journal of Civil Engineering and Technology (IJCIET), 8(8), 2017, 239-250. 
Flexural Behavior of the Structural Concrete Reinforced with Steel and Polypropylene Fibers

[3] Karthikeyan, S. y Elangovan, A.A. Characteristic strength comparison in concrete by the influence of fiberous materials. International Journal of Civil Engineering and Technology (IJCIET), 8(8), 2017, 264-272.

[4] Saeed, R. A Case Study on Concrete Column Strength Improvement with Different steel fibers and polypropylene fibers. Journal of Materials Research and Technology, 8(6), 2019, 6106-6114, doi: https://doi.org/10.1016/j.jmrt.2019.10.005

[5] Hernández, R., Fernández, C. y Baptista, P. Metodología de la investigación. México D.F.: McGRAW-HILL, 2014, pp. 634.

[6] ASTM C136 Standard Test Method for Sieve Analysis of Fine and Coarse Aggregates. American Society for Testing and Materials (ASTM), 2019.

[7] NTP 400.012 Agregados. Análisis granulométrico del agregado fino, grueso y global. 2da. Edición. Norma Técnica Peruana (NTP), 2001.

[8] ASTM C192 Standard Practice for Making and Curing Concrete Test Specimens in the Laboratory. American Society for Testing and Materials (ASTM), 2019.

[9] Sika. Fiber CHO 65-35-NB, Edición 6. Lima, 2015.

[10] NTP 339.035 Concreto. Método de ensayo para la medición del asentamiento del concreto de Cemento Portland. 4a. Edición. Norma Técnica Peruana (NTP), 2015.

[11] NTP 339.078 Concreto. Método de ensayo para determinar la resistencia a la flexión del concreto en vigas simplemente apoyadas con cargas a los tercios del tramo. 3ra. Edición. Norma Técnica Peruana (NTP), 2012.

[12] ASTM C78 Standard Test Method for Flexural Strength of Concrete (Using Simple Beam with Third-Point Loading). American Society for Testing and Materials (ASTM), 2018.

[13] ASTM C33 Standard Specification for Concrete Aggregates. American Society for Testing and Materials (ASTM), 2018.

[14] Cementos Pacasmayo S.A.A. (2018). Especificación técnica Cemento Extraforte (ICo). Recuperado de http://35.188.227.203/img/productos/extraforte.pdf

[15] ACI. Diseño de mezclas de concreto. American Concrete Institute (ACI), 2010.

[16] NTP 334.090 Cementos. Cementos Portland adicionados. Requisitos. 1a. Edición. Norma Técnica Peruana (NTP), 2001.

[17] ASTM C143 Standard Test Method for Slump of Hydraulic Cement Concrete. American Society for Testing and Materials (ASTM), 2015.

[18] NTP 339.034 Concreto. Método de ensayo normalizado para la determinación de la resistencia a la compresión del concreto en muestras cilíndricas. 4a. Edición. Norma Técnica Peruana (NTP), 2015.

[19] Alwesabi, E.A.H., Bakar, B.H.A., Alshaikh, I.M.H. and Akil, H.M. Experimental investigation on mechanical properties of plain and rubberised concretes with steelpolypropylene hybrid fibre. Construction and Building Materials, 233(2020), 2019, 117194, doi: https://doi.org/10.1016/j.conbuildmat.2019.117194

[20] Sarta, H.N. y Silva, J.L. Análisis comparativo entre el concreto simple y el concreto con adición de fibra de acero al 4\% y 6\%. Ingeniero civil, Disertación, Bogotá: Universidad Católica de Colombia, 2017.

[21] Armas, C. Efectos de la adición de fibra de polipropileno en las propiedades plásticas y mecánicas del concreto hidráulico. Rev. Ingeniería: Ciencia, Tecnología e Innovación, 3(2), 2016, 79-91. http://revistas.uss.edu.pe/index.php/ING/article/view/436/425 
[22] Ortiz, S.L. Determinación de la influencia de la fibra de acero en el esfuerzo a flexión del concreto para un $\mathrm{f}^{\prime} \mathrm{c}=280 \mathrm{~kg} / \mathrm{cm}^{2}$. Ingeniero civil, Disertación, Cajamarca-Perú: Universidad Nacional de Cajamarca, 2015.

[23] Villanueva, E.O. y Yaranga, H. Estudio de la influencia de fibras de polipropileno provenientes de plásticos reciclados en concretos de $\mathrm{f}^{\prime} \mathrm{c}=210 \mathrm{~kg} / \mathrm{cm}^{2}$ en el distrito de Lircay, provincia de Angaraes, región Huancavelica. Ingeniero civil, Disertación, LircayPerú: Universidad Nacional de Huancavelica, 2015.

[24] Patil, A.D. and Shinde, D.N. Experimental Study on Characteristic Strengths of Steel Fiber Reinforced Concrete. International Research Journal of Engineering and Technology (IRJET), 3(6), 2016, 1765-1769. https://www.irjet.net/archives/V3/i6/IRJETV3I6328.pdf

[25] Badogiannis, E.G., Christidis, K.I. and Tzanetatos, G.E. Evaluation of the mechanical behavior of pumice lightweight concrete reinforced with steel and polypropylene fibers. Construction and Building Materials, 196, 2019, 443-456, doi: https://doi.org/10.1016/j.conbuildmat.2018.11.109

[26] De Alencar, V.M., Reis, L. and De Andrade, F. On the mechanical behavior of polypropylene, steel and hybrid fiber reinforced self-consolidating concrete. Construction and Building Materials, 188, 2018, 280-291, doi: https://doi.org/10.1016/j.conbuildmat.2018.08.103

[27] Afroughsabet, V. and Ozbakkaloglu, T. Mechanical and durability properties of highstrength concrete containing steel and polypropylene fibers. Construction and Building Materials, 94, 2015, 73-82, doi: http://dx.doi.org/10.1016/j.conbuildmat.2015.06.051

[28] Mythili, T., Vidhya, T. and Balaraman, R. Study on strength characteristics of waste glass powder and steel fibre in concrete. International Journal of Civil Engineering and Technology (IJCIET), 8(8), 2017, 121-128.

[29] Mastali, M., Dalvand, A., Sattarifard, A.R., Abdollahnejad, Z. and Illikainen, M. Characterization and optimization of hardened properties of selfconsolidating concrete incorporating recycled steel, industrial steel, polypropylene and hybrid fibers. Composites Part B, 151, 2018, 186-200, doi: https://doi.org/10.1016/j.compositesb.2018.06.021

[30] Mashrei, M.A., Sultan, A.A. and Mahdi, A.M. Effects of polypropylene fibers on compressive and flexural strength of concrete material. International Journal of Civil Engineering and Technology (IJCIET), 9(11), 2018, 2208-2217.

[31] Al-Katib, H.A.A., Alkhudery, H.H. and Al-Tameemi, H.A. Behavior of polypropylene fibers reinforced concrete modified with high performance cement. International Journal of Civil Engineering and Technology (IJCIET), 9(5), 2018, 1066-1074.

[32] Chapoñan, J.M. y Quispe, J. Análisis del comportamiento en las propiedades del concreto hidráulico para el diseño de pavimentos rígidos adicionando fibras de polipropileno en el A.A.H.H Villamaría-Nuevo Chimbote. Ingeniero civil, Disertación, Chimbote-Perú: Universidad Nacional del Santa, 2017.

http://repositorio.uns.edu.pe/bitstream/handle/UNS/2724/42998.pdf?sequence=1\&isAllow ed=y

[33] Condori, J.L. Análisis de la incidencia de las fibras de acero Dramix en el comportamiento elástico del concreto empleando el cemento portland tipo IP. Ingeniero civil, Disertación,

Juliaca-Perú: Universidad Andina Néstor Cáceres Velásquez, 2016. http://repositorio.uancv.edu.pe/handle/UANCV/729

[34] Millán, M.F. Comportamiento del hormigón reforzado con fibras de polipropileno y su influencia en sus propiedades mecánicas en el cantón Ambato, provincia de Tungurahua. Ingeniero civil, Disertación, Ambato-Ecuador: Universidad Técnica de Ambato, 2013. 